\title{
THE EFFECTIVENESS OF PROBLEM BASED LEARNING (PBL) APPROACH VIEWED FROM THE STUDENTS' MATHEMATICAL CREATIVE THINKING ABILITY
}

\author{
Lisda Fitriana Masitoh ${ }^{1)}$ \\ 1) Pamulang University, South Tengerang \\ E-mail: lisda.masitoh@gmail.com
}

\begin{abstract}
Generally, mathematical competence equips students with logical thinking ability. On the other hand, the mathematical competence is expected to equip students with creative thinking ability. Creative thinking ability is used when a person faces a problem or challenge. Nowadays, there has been a lot of developing approaches that can be used to create ideal learning condition to achieve the learning goals, including improving the mathematical creative thinking ability. One of approaches that can be used is Problem Based Learning (PBL). The purpose of this research was to describe the effectiveness of PBL approach in terms of mathematical creative thinking ability. This was a quasiexperimental reseach. A control class used the conventional approach. The results showed that Problem Based Learning (PBL) was an effective appoach viewed from the mathematical creative thinking ability. Meanwhile, the control class was not effective.
\end{abstract}

Keywords: creative thinking, mathematics, problem based learning

\section{INTRODUCTION}

Learning mathematics in higher education is one of the efforts to equip students to become a quality generation of people who are able to deal with times. This is because mathematics is a science that makes an extraordinary contribution to the development of science and technology. Mathematical competence opens doors to productive futures and lack of competence keep those doors close (NCTM, 2000: 5). Many abilities can be developed through mathematics, one of which is creative thinking ability. The creative thinking ability is very important because it is needed when someone faces problem or challenge.

Creativity is the process of taking new ideas and generating the appropriate and high quality products (Wrigth, 2010: 3). Creativity involves divergent thinking which is the ability to get new and original ideas that become unusual (McGredor, 2007: 168). Two ways of looking at creativity, namely creativity refers to specific types of thinking or certain mental functions called divergent thinking, and creativity refers to producing creative products (Haylock: 1997: 68).

Creativity is closely related to divergent thinking, which is thinking to get new and original ideas. Creativity is very important for students especially in problem solving process. Seifert (1983: 205) defines creativity as a rational emphasis, the quality of problem solving, creativity as a mental expression or self-actualization, and creativity as a result of thinking. Because creativity is closely related to the thinking process, creativity is often called creative thinking.

Creative thinking is one type of thinking that is very interesting which is related to cognitive skills and the ability to find new solutions of problem (Arends \& Kilcher, 2010: 233). Characteristics of creative thinking are original results and new ways that are not previously predicted (Crow \& Crow, 1977: 448). Creative thinking is closely related to ideas to find solutions of problem. Therefore creative thinking in mathematics is closely related to the process to solve problems. Guilford (Lefrancois, 2000: 301) stated that creativity involves fluency, flexibility, and originality.

Creative thinking that involves divergent thinking, is explained by Schlichter (Eragamreddy, 2013: 140) who stated that in general the meaning of divergent thinking includes fluency (thinking about many ideas), flexibility (thinking from a different point of view), originality (thinking about unusual ideas) and elaboration (adding detailed solutions to enhance ideas). Creative thinking has originality, which is unusual thinking, smart, new ideas. Flexibility means thinking about new ideas and ways to overcome the situation, fluency comes through how much the number of ideas, words and ways of expressing something. Meanwhile, elaboration is enriching experience through details (Gorman, 1974: 275). 
According to Ali (2010: 5) aspects of creative thinking in mathematics are fluency, flexibility, novelty and elaboration. Fluency includes the ability to solve problems and provide many answers to the problem or provide many examples or statements related to certain mathematical concepts or situations. Flexibility includes the ability to use a variety of problem solving strategies or provide various examples or statements related to certain mathematical concepts or situations. Novelty includes the ability to use strategies that are new, unique, or unusual to solve problems or provide examples or statements that are new, unique, or unusual. Elaboration includes the ability to explain in detail and coherence to mathematical procedures, answers, or certain mathematical situations.

Based on the description above, it can be concluded that in general the mathematics creative thinking ability is the ability to obtain ideas to solve problems that include fluency, flexibility, originality and elaboration. Fluency is shown through the ability to solve problems and provide many answers. Flexibility is shown through the ability of students to use various ways or strategies to solve problems and produce a variety of answers. The originality is shown through the ability of students to solve problems in new ways or strategies or provide new (unusual) answers. Meanwhile elaboration is shown through the ability of students to solve problems with detailed and coherent steps.

Everyone has the ability to think creatively. It is just that their abilities are not the same and these abilities can be developed. The creative thinking level of each person is different from one to each other. There are five levels of creative thinking skills from the lowest to the highest (Tatag, 2010: 17). Everyone has at least some creative potential. The difference is the extent to which the person is able to realize this potential (Wrigth, 2010: 3).

Students can improve mathematical creative thinking ability by practicing math problems. In this case, the lecturer facilitates students to improve their mathematical creative thinking ability. Efforts to improve students' creative thinking ability are carried out by increasing students' abilities in creative thinking aspects, namely fluency, flexibility, originality and elaboration.

Creative thinking as previously explained is very closely related to problem solving. Therefore, mathematical problems become the base for developing students' mathematical creative thinking ability. Developing students' creative thinking ability can be done using open-ended problems. Open-ended problem is questions that have various solutions or strategies to solve (Ali, 2010: 1).

In general, improving the creative thinking ability can be done through problem solving, including the problem solving in open-ended problems. Through problem solving, fluency can be trained with problems that produce answers. Flexibility is trained through problems that can be solved in several ways or in various answers. Originality is trained through problems that give students freedom to give correct answers, including flexibility in using methods or strategies. Meanwhile elaboration is trained through solving problems in a detailed and coherent manner.
Another thing that must be done is to evaluate students' thinking ability. The evaluation of students' creative thinking ability is important to find out the level of students' creative thinking ability. To evaluate the creative thinking ability, students can use tasks that require them to do problem solving activities. The type of problem solving that can be used in evaluating students' creative thinking ability is open-ended problem. According to Ali (2010: 1), one way to evaluate the creative thingking ability is with open-ended problem, namely problems that have a variety of solutions or strategies. The result of problem solving is analyzed to determine the level of students' creative thinking ability.

Based on the statements above, it can be concluded that problem solving activities can be used to improve and evaluate the creative thinking ability. One of the problems that can be used is an open-ended problem, which is a problem that has a variety of solutions or strategies.

The above description suggests that students should have high creative thinking ability and can use it in solving problems, especially mathematical problems. However, the facts that occurred at Pamulang University, especially in the Informatics Engineering Study Program, showed that students' creative thinking ability was still relatively low. Students' creativity in working on mathematicsl problems is still lack. Mathematics was not a subject that most students like.

Based on the results of interview with several students in the Informatics Engineering Study Program, it was known that students did not like Mathematics, especially applied graph. In addition, they were also not confident with their mathematical abilities. They have assumed that Mathematics is difficult and they cannot comprehend it. About creative thinking ability, in particular the initial description of students' creative thinking ability in the Informatics Engineering Study Program was obtained based on the students' creative thinking ability test in the subject of applied graph by giving tests to 60 students. The results showed that most students have not been able to provide many answers in solving a problem. This showed that students' creative thinking ability was still low and absolutely still needs to be improved.

The efforts to improve students' creative thinking ability can be done by improving the process of learning Mathematics. A teacher, in this case the lecturer, must prepare their best for mathematics learning activities, including using various learning approaches. One of the goals is to realize an interactive and fun mathematics learning and can facilitate students in improving their creative thinking ability.

Related to efforts to improve the creative thinking ability, the alternative learning approache that can be used is Problem Based Learning (PBL). PBL is a learning strategy designed to improve learning by requiring students to study subject matter while solving problems (Jonassen, 2011: 154). Problem solving activities that carried out by students in PBL will bring students to problem solving skills. PBL uses problems as a means for students to acquire problem solving skills and gain knowledge (Uden \& Beaumont, 2006: 25). PBL is a student-centered model, developing activeness and learning motivation, problem-solving skills and broad knowledge, the 


\section{- - - Jurnal Pendidikan Matematika Indonesia \\ Volum 4 Nomor 2 bulan September 2019 Page 47 - 52 \\ p-ISSN: 2477-5967 e-ISSN: 2477-8443}

basis of deep understanding and problem solving (Ali, et al, 2010: 68).

Learning activities through PBL emphasize the need of students to investigate problems presented and construct knowledge based on their experiences. Torp \& Sage (2002: 15) stated that PBL is focused learning, learning from organized experiences through investigation and is the resolution of real world problems. The investigation process is carried out both individually and in groups (Arend \& Kilcher, 2010: 127).

Investigation involves students actively in learning and allows students to identify problems, understand problems and solve problems, until finally students gain new knowledge. The investigation process requires students to think critically, creatively and monitor their understanding (Sungur \& Tekkaya, 2006: 308). This opinion shows that PBL places students as the center of learning activities and provides learning facilities for students to develop the ability to think critically and creatively. This is consistent with the opinion of Chakrabarty \& Mohamed (2013: 40) that PBL is learning about problem solving that gives students the opportunity to think critically and convey their creative ideas. PBL is learning that can help students improve their creative thinking ability (Uden \& Beaumont, 2006: 41).

Therefore, one of the thinking abilities that can be developed through PBL is the creative thingking ability. The proposed problem is the problem that trains students to solve problems and requires creative thinking (Bilgin, Senocak \& Sozbilir, 2009: 155). PBL illustrates something that has the potential to increase creative thinking (Wu \& Forrester, 2004: 75). Learning with the PBL approach uses problems as the starting point of students in constructing their knowledge. The problem must be solved by students, so that through the problem solving process students can improve their creative thinking ability.

Some experts find their opinions regarding the learning syntax with PBL. Arend \& Kilcher (2010: 333) described that PBL starting from presenting problems and organizing students to study in groups. The groups of student are then asked to design and plan investigations to find possible solutions. The development of students' learning is monitored by the lecturer and students. Finally, the groups presented their findings and participated in reflection and question and answer. According to Arends (2008: 57) the steps of learning with PBL were carried out by giving orientation of the problem to students, organizing students to research, assisting independent and group investigations, developing and presenting artifacts and exhibits and finally evaluating the problem solving process.

Generally, it can be concluded that important points from learning with the PBL approach with five main steps, namely preparing students, orientation of the problem, investigation, presentation and evaluation. In the first step of preparing students, the lecturer organizes students to learn. In the second step of orientation of the problem, the lecturer can propose a phenomenon or problem that is the basis for students to learn. Next, students define the main problem they will solve, and what is needed to solve the problem.
The third step is investigation. In this step students conduct an investigation, discuss looking for ideas to get a solution to the problem. At this stage students try to find the most appropriate solution. Therefore, after getting a solution students need to looking back and correct the results of the problem solving, so that they are truly confident in the solution they get. The next step is presentation. This activity facilitates students in delivering the results of the problem solving. The last stage is evaluation. In evaluation activities, students reflect or evaluate their investigations and the processes they use in solving problems.

Based on the description above, the researcher intends to find out the effectiveness of the Problem Based Learning approach in terms of students' mathematical creative thinking ability, especially in the subjects of applied graph. The conventional class will be chosen as the control class.

\section{METHOD}

This is a quasi-experimental research. Quasi-experimental research is based on the assumption that the classes used as experiments are equivalent. In experimental research the hypothesis regarding casual relationships (causation) will be tested correctly (Gay 1981: 85). In this case the Problem Based Learning approach will be applied and will be compared with conventional approach to see the consequences that are caused, especially in the dependent variable to be studied, namely the mathematical creative thinking ability. The research was conducted from March to May 2018, in the even semester period 2017/2018 academic year. The place of the research was at Pamulang University.

The data collection methods used in this research were interviews, documentation and tests. In particular, data of mathematical creative thinking ability were carried out using written tests. The test was carried out before treatment to determine students' initial mathematical creative thinking ability before getting treatment. After that the test was carried out again after the treatment was given to determine the students' mathematical thinking ability after getting treatment. The data analysis used in this study is descriptive analysis and inferential analysis with calculations using the SPSS program.

\section{A. Descriptive Analysis}

The data analysed in this research were pretest and posttest on the aspects of creative thinking ability. The data presented are mean, standard deviations, the highest score achieved, the lowest score achieved, the maximum possible score, and the minimum possible score. The data of creative thingking ability was obtained through measurement with test instruments. For learning achievement tests, the instrument used was essay test. Furthermore, data about creative thingking ability are interpreted into specified criteria. To determine criteria, classification is used based on ideal averages and ideal standard deviations. The conversion score of creative thinking ability refers to the following table. 


\section{- - - Jurnal Pendidikan Matematika Indonesia \\ Volum 4 Nomor 2 bulan September 2019 Page 47 - 52 \\ p-ISSN: 2477-5967 e-ISSN: 2477-8443}

Table I

Conversion Score of Creative Thinking Ability

(Quantitative to Qualitative with Five Scale)

\begin{tabular}{cc}
\hline Score Interval & Criteria \\
\hline$X>75$ & Very good \\
$58.33<X \leq 75$ & Good \\
$41.67<X \leq 58.33$ & Fair \\
$25<X \leq 41.67$ & Bad \\
$X \leq 25$ & Very bad \\
\hline
\end{tabular}

\section{B. Inferential analysis}

The techniques of data analysis that used was univariate analysts with pre-trial tests, namely normality test and homogeneity test. The analysis was carried out with the SPSS program. The learning approach is said to be effective if the mean score of student is more than or equal to 70 . The test used was one sample t-test to find out the effectiveness of each approach. Test of one sample t-test can be done if the data comes from a normal distribution population. If both PBL and conventional approaches are effective, then a comparative test of the effectiveness of the learning approach is carried out using the Analysis of Variance (ANOVA) test.

If the results of the univariate test have different effectiveness between the two learning approaches, then further testing (post hoc) is conducted to see which learning approach is more effective. However, if the results of multivariate tests show that there is no difference in effectiveness between the two learning approaches, further testing is not carried out.

\section{RESULTS AND DISCUSSION}

\section{A. Data of Creative Thingking Ability}

The data in this study were divided into two, namely data before treatment and data after being treated. The data includes pretest and posttest about creative thinking ability. The following is a description of the results of the test of creative thinking ability, both those who received the PBL approach and the conventional approaches presented in Table below.

Table II

Result of Creative Thingking Ability

\begin{tabular}{lcccc}
\hline \multirow{2}{*}{ Description } & \multicolumn{2}{c}{ Problem Based Learning } & \multicolumn{2}{c}{ Conventional } \\
\cline { 2 - 5 } & Pretest & Posttest & Pretest & Posttest \\
\hline Mean & 11.83 & 76.79 & 11.28 & 69.24 \\
Standard & 6.38 & 5.60 & 4.90 & 9.65 \\
deviation & 100 & 100 & 100 & 100 \\
Maximum score & 0 & 0 & 0 & 0 \\
Minimum score & 25 & 90 & 25 & 85 \\
Highest score & 0 & 65 & 0 & 50 \\
Lowest score & $0 \%$ & $95.83 \%$ & $0 \%$ & $58.62 \%$ \\
Complete the & & & & \\
test $(\%)$ & & &
\end{tabular}

Based on the table above, the mean of posttest score of students' creative thinking ability is more than the mean of pretest score of the class that gets treatment using both PBL and conventional approaches. The mean of creative thinking ability for PBL class increased from pretest with a score of 11.83 to 76.79 at posttest, this showed that there was an increase of 64.96. These results indicate that the mean score of students after being treated has reached the specified minimum criteria of 70 . For conventional class, the mean score of students' thinking ability from pretest with a score of 11.28 to 69.24 at posttest means that it increases by 57.96 . While based on the percentage of student completed the test, before being given treatment there were no students who completed or reached a score of 70 . Then after being given treatment, the percentage of student completed the test in the PBL class reached $95.83 \%$. Exactly, 23 of the 24 students did. While the conventional class reached $58.62 \%$ or 17 of 29 students. The frequency distribution of students' creative thinking ability can be seen in table below.

Table III

Frequency Distribution of Students' Creative Thinking Ability

\begin{tabular}{|c|c|c|c|c|c|c|c|c|}
\hline \multirow{3}{*}{ Criteria } & \multicolumn{4}{|c|}{ Problem Based Learning } & \multicolumn{4}{|c|}{ Conventional } \\
\hline & \multicolumn{2}{|c|}{ Pretest } & \multicolumn{2}{|c|}{ Posttest } & \multicolumn{2}{|c|}{ Pretest } & \multicolumn{2}{|c|}{ Posttest } \\
\hline & $\mathbf{F}$ & $\%$ & $\mathbf{f}$ & $\%$ & $\mathbf{f}$ & $\%$ & $\mathbf{f}$ & $\%$ \\
\hline $\begin{array}{l}\text { Very } \\
\text { Good }\end{array}$ & 0 & $0 \%$ & 11 & $45.83 \%$ & 0 & $0 \%$ & 5 & $17.24 \%$ \\
\hline Good & 0 & $0 \%$ & 13 & $54.17 \%$ & 0 & $0 \%$ & 19 & $65.51 \%$ \\
\hline Fair & 0 & $0 \%$ & 0 & $0 \%$ & 0 & $0 \%$ & 4 & $13.79 \%$ \\
\hline $\mathrm{Bad}$ & 0 & $0 \%$ & 0 & $0 \%$ & 0 & $0 \%$ & 0 & $0 \%$ \\
\hline $\begin{array}{l}\text { Very } \\
\text { bad }\end{array}$ & 24 & $100 \%$ & 0 & $0 \%$ & 29 & $100 \%$ & 0 & $0 \%$ \\
\hline
\end{tabular}

Based on the table above, class of PBL showed that when before being treated all students had very poor creative thinking ability, as many as 24 students or $100 \%$ of the class. Then after being given treatment using the PBL approach it can be seen that as many as 11 students or $45.83 \%$ had very good creative thinking ability and the remaining 13 students or $54.17 \%$ were in good criteria.

While in the class with conventional methods, it can be seen that when before being treated, all students had very poor creative thinking skills. Then after being given a treatment using a conventional approach, it can be seen that as many as 5 students or $17.24 \%$ had very good criteria of creative thinking ability, 19 students or $65.51 \%$ were in good criteria and the remaining 4 students or $13.79 \%$ were in fair criteria.

\section{B. Result of Hypothesis Test}

The significance value of the posttest data of creative thinking ability for PBL was $0.00<\alpha=0.05$, so it could be concluded that PBL approach was effective in terms of mathematical creative thinking ability. While the significance value of the posttest data of creative thinking ability for conventional class was $0.679<\alpha=0.05$, so it could be concluded that conventional approach was not effective in terms of mathematical creative thinking ability.

The effectiveness of PBL approach has also been proven by previous research,that was research by Fadrik (2017) that PBL was effective in improving students' creative thinking ability in the Mathematics Education Study Program of UIN Mataram. In addition, the results of research conducted by 
Ima, et al (2015) showed that PBL was effectively used to improve the creative thinking ability of students of Biology Education study program of Sebelas Maret University.

Because the results of testing the effectiveness of conventional approach showed that conventional approach was not effective in terms of creative thinking ability, the analysis was not continued to determine the differences in the effectiveness of PBL and conventional approaches in terms of students' mathematical creative thinking ability.

\section{CONCLUSION}

Based on the results of data analysis and discussion that have been described previously, it can be concluded that the Problem Based Leaning Approach (PBL) was effective viewed form the students' mathematical creative thinking ability. While conventional approach was not effective. From these results it is recommended for teachers in higher education to be able to apply the PBL approach in learning mathematics in the classroom.

\section{REFERENCES}

Ali, Mahmudi. (2010). Mengukur kemampuan berpikir kreatif matematis. Dipresentasikan dalam Konferensi Nasional Matematika XV. Manado: UNIMA.

Ali, R., et al. (2010). Effect of using problem solving method in teaching mathematics on the achievement of mathematics students. Asian Social Science, 6 (2), 66-72.

Arends, R. I. (2008). Learning to teach: belajar untuk mengajar. (Terjemahan Helly Prajitno Soetjipto \& Sri mulyani Soetjipto). New York, NY: McGraw Hill Companies. (Buku asli diterbitkan tahun 2007).

Arends, R. I., \& Kilcher, A. (2010). Teaching for student learning: Becoming an accomplished teacher. New York, NY: Taylor \& Francis Group.

Bilgin, I., Senocak, E., \&Sozbilir, M. (2009). The effect of problem based learning instruction on university students performance of conceptual and quantitative problem in gas concepts. Eurasia Journal of Mathematics, Science \& Technology Education, 5 (2), 153-164.

Chakrabarty, S., \& Muhamed, N. (2013). Problem based learning: Cultural diverse students' engagement, learning and contextualized problem solving in a mathematics class. Wcik E-Journal of Integration Knowledge, 38-49.

Crow, L. D., \& Crow, A. (1977). Psikologi pendidikan. (Terjemahan Drs. Z. Kasijan). New York, NY:
American Book Company. (buku asli diterbitkan tahun 1954).

Eragamreddy, N. (2013). Teaching creative thinking skills. International Journal of English Language \& Translation Studies, 1 (2), 124-145.

Fadrik, A.,F. (2017). Efektivitas Problem Based Learning Terhadap Kemampuan Berpikir Kreatif Mahasiswa Program Studi Tadris Matematika UIM Mataram. Jurnal Teori dan Aplikasi Matematika, 1 (1), 48-54.

Gay, L.R. (1981). Education Research: Competencies for Analisis and Aplication. Columbus:Charles E. Merrill Publishing Company.

Gorman, R. M. (1974). The psychology of classroom learning: an inductive approach. Columbus, $\mathrm{OH}$ : Meril Publisjing Company.

Haylock, D. (1997). Recognizing mathematical creativity in school children. Zentralblattfur Didaktik der Mathematics, 29 (3), 68-74.

Ima, et al. (2015) Pengembangan Modul Problem Based Learning (PBL) pada Materi Populasi Hewan untuk Meningkatkan Kemampuan Berpikir Kreatif Mahasiswa Pendidikan Biologi Universitas Sebelas Maret. Jurnal Pendidikan IPA Inkuiri, 4 (3), 1-6.

Jonassen, D. H. (2011). Learning to solve problem: A handbook for designing problem solving learning environments. New York, NY: Routledge.

Lefrancois, G. R. (2000). Psychology for teaching. London: Wadsworth Thamson Learning.

McGredor, D. (2007). Developing thinking; developing learning: A guide to thinking skills in education. New York, NY: Open University Press.

NCTM. (2000). Principles and standards for school mathematics. Reston, VA: The National.

Seifert, K. S. (1983). Educational psycology theory and practice. Norfolk, MA: Pearson Education Company.

Sungur, S., \& Tekkaya, C. (2006). Effect of problem based learning and traditional instruction on self-regulated learning. The Journal of Educational Research, 99 (5), 307-317.

Tatag, Y. E. S. (2010). Leveling student creative thinking in solving and posing mathematical problem. Journal on Mathematics Education, 1 (1), 17-40. 
Torp, L., \& Sage, S.(2002). Problem as possibilities: Problem based learning for K-16 education (2nd ed). Alexandria, VA: ASCD.

Uden, L., \& Beaumont, C.( 2006). Technology and problem based learning. Hershey, PA: Idea Group.

Wrigth, S. (2010). Understanding creativity in early childhood. London: SAGE Publication Ltd.

Wu, W. Y., \& Forrester, V. (2004). Exploring the cognitive processes of problem-based learning and their relationship to talent development. Dalam Tan, O. S \& Watson, G. Enhancing Thinking Through Problem-Based Learning Approaches: International Perspectives (pp. 64-77). Singapore: Cengage Learning 